\title{
Structure, function and regulation of $\mathrm{Ca}_{\mathrm{V}} 2.2 \mathrm{~N}$-type calcium channels
}

\author{
Bohumila Jurkovicova-Tarabova ${ }^{1}$ and Lubica Lacinova ${ }^{1,2}$ \\ ${ }^{1}$ Center of Biosciences, Institute of Molecular Physiology and Genetics, Academy of Sciences, Dubravska cesta 9, \\ 84005 Bratislava, Slovakia \\ ${ }^{2}$ Faculty of Natural Sciences, University of Ss. Cyril and Methodius, Trnava, Slovakia
}

\begin{abstract}
N-type or $\mathrm{Ca}_{\mathrm{V}} 2.2$ high-voltage activated calcium channels are distinguished by exclusively neuronal tissue distribution, sensitivity to $\omega$-conotoxins, prominent inhibition by G-proteins, and a unique role in nociception. Most investigated modulatory pathway regulating the $\mathrm{Ca}_{\mathrm{V}} 2.2$ channels is G-protein-coupled receptor-activated pathway leading to current inhibition by G $\beta \gamma$ subunit of G-protein. Binding of G $\beta \gamma$ dimer to $\alpha_{1}$ subunit of the Cav2.2 channel transfers the channel form "willing" to "reluctant" gating state. Channel phosphorylation by protein kinase C potentiates N-type calcium current. $\mathrm{Ca}_{2} 2.2$ channels could be functionally regulated also by a number of protein-protein interactions. $\mathrm{Ca}_{\mathrm{V}} 2.2$ null mice are hyposensitive to inflammatory and neuropathic pain, otherwise they have a mild phenotype. Consistent with the mild phenotype of the $\mathrm{Ca}_{\mathrm{V}} 2.2^{-{ }_{-}^{-}}$mice, reports on mutations linked to a disease phenotype are scarce. Only one mutation related to human heritable diseases was identified until now. Pharmaceutical inhibition of $\mathrm{Ca}_{\mathrm{V}} 2.2$ channels either by direct inhibition of the channel, by an activation of G-protein coupled receptors, or by inhibition of membrane targeting of the channel protein are promising strategies for treatment of severe chronic and/or neuropathic pain.

Key words: $\mathrm{N}$-type calcium current $-\mathrm{Ca}_{\mathrm{V}} 2.2$ channel - Aauxiliary subunits $-\mathrm{G}$-protein regulation $-\mathrm{G}_{\beta \gamma}$ subunit - Channel gating - Channelopathies - Inflammatory pain - Neuropathic pain - Proteomic analysis
\end{abstract}

\section{Introduction}

N-type or $\mathrm{Ca}_{\mathrm{V}} 2.2$ calcium channels belong to the family of high-voltage activated calcium channels. Nowycki, Fox, and Tsien (Nowycky et al. 1985) were the first to suggest existence of three types of Ca channel in sensory neurones of the chick dorsal root ganglion. In addition to already known L-type and T-type currents they identified a third type of conductance - "N", that was neither T nor L. N-type calcium current was distinguished from an L-type by more negative voltage threshold for current inactivation and insensitivity to dihydropyridines, from a T-type it differed in more positive voltage threshold for activation. Soon thereafter, Wanke and coauthors (Wanke et al. 1987) demonstrated that N-type channels in

Correspondence to: Lubica Lacinova, Center of Biosciences, Institute of Molecular Physiology and Genetics, Slovak Academy of Sciences, Bratislava, Slovakia

E-mail: lubica.lacinova@savba.sk superior cervical ganglions of rat are regulated by muscarinic pathway via pertussis toxin-sensitive G-proteins. Gross and Macdonald (1987) suggested modulation of N-type calcium current in mouse dorsal root ganglion (DRG) neurons by opioid receptors-related pathway. As a pharmacological tool for isolation of N-type calcium channels $\omega$-conotoxins were established (Reynolds et al. 1986; Kasai et al. 1987).

Cloning of genes for individual calcium channel proteins during 1990-ties enabled extensive studies of their structure, regulation, and tissue distribution. Also, it formed a basis for new systemic nomenclature of voltage-gated ion channels. $\mathrm{N}$-type calcium channel was named $\mathrm{Ca}_{\mathrm{V}} 2.2$ in this nomenclature (Ertel et al. 2000).

Unique role of $\mathrm{N}$-type in nociception was established (Malmberg and Yaksh 1994b; Omote et al. 1996). Additionally, dysregulation of these channels in fragile X mental retardation (Ferron et al. 2014) was reported and gain-of-function mutation associated with myoclonus-dystonia syndrome was identified in one family (Groen et al. 2015). 


\section{Cloning of the Cav $2.2 \alpha_{1}$ subunit}

In early 1990-ties, several cDNAs clones encoding $\alpha_{1}$ subunits homologous to $\alpha_{1}$ heart and skeletal subunit were isolated and characterized from rat brain (Snutch et al. 1990). Next, $240 \mathrm{kDa}$ protein of $\mathrm{N}$-type channel was detected by photolabeling and its association with $\alpha_{2} \delta$ subunit was evidenced (Ahlijanian et al. 1991). One year later, full-length sequence of 2336 amino acid protein of $\alpha_{1 B}$ subunit in rat brain was described and immunoprecipitation labeling experiments restricted its expression to nervous system of the rat forebrain (Dubel et al. 1992). Westenbroek and coauthors recognized in rat brain two $a_{1 B}$ proteins with sizes of 240 and $210 \mathrm{kDa}$ localized complementary in dendrites, nerve terminals and cell bodies of most neurons (Westenbroek et al. 1992). Immunoprecipitation experiments showed presence of at least two different forms of $\alpha_{1}$ subunits forming N-type calcium channel complex (Westenbroek et al. 1992). Human neuronal $\alpha_{1}$ subunit designated as $\alpha_{1 B}$ was identified in human neuroblastoma cells and central nervous system (Williams et al. 1992a, 1992b). Consistent with cloning of two isoforms of rat $\mathrm{N}$-type calcium channel, two isoforms of human calcium channel $\alpha_{1 B}$ subunit differing in their Cterminus were identified: the $\alpha_{1 \mathrm{~B}-1}$ comprising 2339 amino acids with the molecular weight of $262 \mathrm{kDa}$ and the $\alpha_{1 \mathrm{~B}-2}$ with 2237 amino acids with the calculated molecular weight of $251 \mathrm{kDa}$.

\section{Auxiliary subunits of the Cav2.2 channel complex}

Expression of several subtypes of the auxiliary subunits gives rise to functionally different heterologous $\mathrm{N}$-type channel complexes (McEnery et al. 1991; Williams et al. 1992b; Witcher et al. 1993; Gao et al. 2000). cDNA cloning analysis revealed expression of $\beta$ subunit with high homology to the $\beta$ subunit of rabbit skeletal DHP-sensitive calcium channel in the rat brain (Pragnell et al. 1991). Following studies identified three different $\beta$ subunits, $\beta 1 b, \beta 3$ and $\beta 4$, which associate with the $\alpha_{1 \mathrm{~B}}$ subunit of $\mathrm{N}$-type calcium channels and account for the diverse channel kinetic properties in different types of neurons (Scott et al. 1996; Witcher et al. 1993).

Generally, expression of principal $\alpha_{1 B}$ subunit in complex with a $\beta$ subunit enhances current through the channel complex by increasing channel expression in plasma membrane and its opening probability. $\beta$ subunit also modulates channel gating by shifting the voltage dependence of its activation and inactivation (Buraei and Yang 2010; Dolphin 2012). Biophysical data has shown that expression of the $\alpha_{1 B}$ subunit of $N$-type calcium channel together with auxiliary $\beta 2$ and $\alpha_{2} \delta$ subunits in HEK 293 cells resulted in barium current with properties typical for $\mathrm{N}$ type current (Williams et al. 1992b). Experiments expressing $\alpha_{1 B}$ subunit together with $\beta 1 \mathrm{~b}$ revealed the increase in the whole-cell current and in rate of activation accompanied by the shift of the voltage-dependence of the inactivation to the hyperpolarized potentials. Results of this study did not show significant effect of co-expression of the $\alpha_{2} \delta$ subunit (Stea et al. 1993). Following study has described decelerated current inactivation, shift of the current-voltage relationship to negative potentials and modified voltage-dependent inactivation when $\beta 1 \mathrm{~b}$ subunit was expressed in the complex with $\alpha_{1 \mathrm{~B}}$. In this study, co-expression of an $\alpha_{2} \delta$ subunit also affected the current properties by accelerating of both current activation and inactivation and by the shifting the I-V slightly to the more positive membrane

Table 1. Effects of co-expression of auxiliary subunits of the Ca 2.2 channel complex on current through the $\alpha_{1 \mathrm{~B}}$ subunit

\begin{tabular}{|c|c|c|}
\hline & Effect on N-type current & Reference \\
\hline \multicolumn{3}{|c|}{ B subunit } \\
\hline \multirow{3}{*}{ ß1b } & $\uparrow \mathrm{I}_{\mathrm{Ca}}$ amplitude, $\uparrow \mathrm{I}_{\mathrm{Ca}}$ activation, negative shift of voltage-dependent inactivation & Stea 1993 \\
\hline & $\downarrow \mathrm{I}_{\mathrm{Ca}}$ inactivation, negative $I$ - $V$ shift, negative shift of voltage-dependent inactivation & Wakamori 1999 \\
\hline & $\uparrow \mathrm{I}_{\mathrm{Ca}}$ inactivation & Canti 2003 \\
\hline \multirow{2}{*}{ ß3 } & $\downarrow \mathrm{I}_{\mathrm{Ca}}$ amplitude, negative shift of voltage-dependent inactivation & Yasuda 2004 \\
\hline & $\uparrow \mathrm{I}_{\mathrm{Ca}}$ amplitude, $\uparrow$ channel expression & Brust 1993, Canti 2003 \\
\hline$\beta 4$ & $\uparrow \mathrm{I}_{\mathrm{Ca}}$ density, negative shift of $\mathrm{I}_{\mathrm{Ca}}$ activation, $\downarrow_{\text {voltage-dependent inactivation }}$ & Canti 2000, Stephens 2000 \\
\hline \multicolumn{3}{|c|}{$\alpha_{2} \delta$ subunit } \\
\hline \multirow{5}{*}{$a_{2} \delta 1$} & $\leftrightarrow \mathrm{I}_{\mathrm{Ca}}$ amplitude & Stea 1993 \\
\hline & $\uparrow \mathrm{I}_{\mathrm{Ca}}$ activation, $\uparrow \mathrm{I}_{\mathrm{Ca}}$ inactivation, positive $I-V$ shift & Wakamori1999 \\
\hline & $\uparrow \mathrm{I}_{\mathrm{Ca}}$ amplitude, $\uparrow$ channel expression & Brust1993, Canti 2003 \\
\hline & $\uparrow \mathrm{I}_{\mathrm{Ca}}$ amplitude, $\uparrow \mathrm{I}_{\mathrm{Ca}}$ inactivation & Gao 2000 \\
\hline & $\leftrightarrow \mathrm{I}_{\mathrm{Ca}}$ activation & Canti 2003 \\
\hline \multirow{2}{*}{$\alpha_{2} \delta 2$} & $\uparrow \mathrm{I}_{\mathrm{Ca}}$ amplitude, $\leftrightarrow \mathrm{I}_{\mathrm{Ca}}$ inactivation & Gao 2000 \\
\hline & $\leftrightarrow \mathrm{I}_{\mathrm{Ca}}$ activation & Canti 2003 \\
\hline
\end{tabular}

Arrows denote effects of auxiliary subunits on biophysical properties of the $\mathrm{Ca}_{\mathrm{V}} 2.2$ channel complex: $\uparrow$ increase/acceleration of the current attribute, $\downarrow$ decrease/slowing of the current attribute, $\leftrightarrow$ no or little effect on current attribute. 
potentials (Wakamori et al. 1999). In contrast, $\beta 3$ demonstrated negative regulatory effect on $\mathrm{N}$-type calcium channel complex suppressing current amplitude under physiological conditions and by shifting voltage-dependent inactivation to negative potentials (Yasuda et al. 2004). In contrast, co-expression of the $\beta 4$ subunit in N-type calcium channel complex resulted in increase in current density, a shift of activation to negative potentials, and deceleration of voltage-dependent inactivation (Canti et al. 2000; Stephens et al. 2000). Co-expression of $\alpha_{2} \delta$ subunit increases current amplitude by increasing an expression of the $\mathrm{N}$-type channel complex in plasma membrane and addition of $\beta 3$ subunit further stimulates membrane trafficking of the channel (Brust et al. 1993; Canti et al. 2000). Functional activity of $\mathrm{N}$-type channel was increased by co-expression of $\beta 3$ or $\beta 1 b$ subunit, respectively, together with either $\alpha_{2} \delta 1$ or $\alpha_{2} \delta 2$ subunit in Xenopus oocytes, showing 9-fold peak current amplitude raise (Canti and Dolphin 2003; Gao et al. 2000). Ntype channel complex with the $\alpha_{2} \delta 1$ but not the $\alpha_{2} \delta 2$ subunit exhibited enhanced channel inactivation (Gao et al.2000). $\alpha_{2} \delta 1$ and $\alpha_{2} \delta 2$ subunits had little effect on kinetics of $N$-type calcium current activation but accelerated current inactivation when coexpressed with the $\beta 1 \mathrm{~b}$ subunit (Canti and Dolphin 2003).

Quantitative proteomic analysis showed that $\beta 4$ followed by $\beta 3$ are most frequently assembled with $\mathrm{Ca}_{\mathrm{V}} 2.2 \alpha_{1}$ subunit while $\beta 1$ is less frequently and $\beta 2$ is rarely forming a part of $\mathrm{Ca}_{V} 2.2$ channel complex (Muller et al. 2010). Recently, it was shown that the auxiliary $\alpha_{2} \delta 1$ subunit is necessary for membrane trafficking of $\alpha_{1 B}$ subunit in dorsal root ganglion neurons and important for trafficking in dorsal horn neurons (Nieto-Rostro et al. 2018).

\section{Role of Cav2.2 channels in physiology and pathophysiology}

Expression of $\mathrm{Ca}_{\mathrm{V}} 2.2$ channels was identified almost exclusively in central and peripheral neurons (Nowycky et al. 1985). These channels are located mainly in dendritic shafts and presynaptic terminals (Westenbroek et al. 1992). They were found in laminae I and II of the dorsal horn and were shown to be predominant at synapses that carry nociceptive information into the spinal cord (Westenbroek et al. 1998). Within II-III domain linker of the $\mathrm{Ca}_{\mathrm{V}} 2.2 \alpha_{1}$ subunit a synaptic protein interaction (synprint) site is located. This site interacts with proteins of the synaptic vesicle release complex, such as syntaxin 1 and SNAP-25 (Sheng et al. 1994, 1996). This interaction stabilizes membrane localization of $\mathrm{Ca}_{\mathrm{V}} 2.2$ channels in close proximity to synaptic vesicles. Incoming action potentials activate large temporally precise calcium influx through $\mathrm{Ca}_{\mathrm{V}} 2.2$ channels and activate release of neurotransmitters like glutamate or substance P (Weber et al. 2010) ensuring transmission of peripheral signals to the brain (Figure 1). This pathway

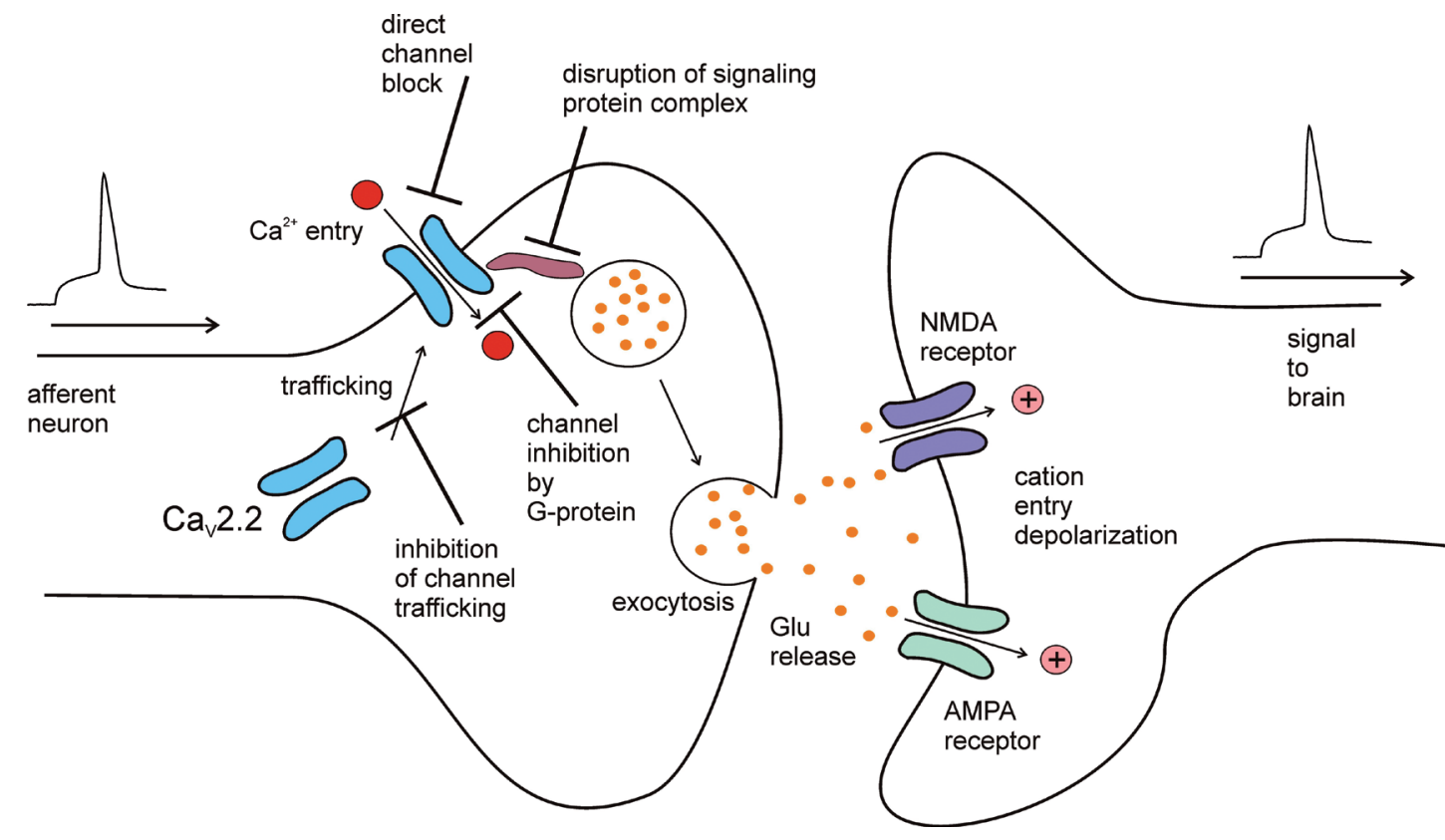

Figure 1. Role of $\mathrm{Ca}_{\mathrm{V}} 2.2$ channels in synaptic transmission. $\mathrm{Ca}_{\mathrm{V}} 2.2$ channels are expressed in presynaptic membrane of afferent nociceptive neurons. They form signaling complex with synaptic vesicles releasing glutamate. Depolarization of presynaptic membrane by incoming action potential results in activation of $\mathrm{Ca}_{\mathrm{V}} 2.2$ channels. Calcium entry through these channels activates exocytosis and glutamate release. Glutamate (Glu) activates corresponding receptors in postsynaptic membrane of dorsal horn neuron. Cations entering through NMDA and AMPA receptors depolarize postsynaptic membrane and initiate signaling to the brain. 
conveys various sensory modalities from peripheral sensory neurons including pain, itch, touch, and perception of body muscle tension (Bourinet et al. 2014). In accord with suggested role of $\mathrm{Ca}_{V} 2.2$ channels in nociception, their inhibition suppressed formaline-induced pain (Malmberg and Yaksh 1994a, 1994b), thermally- and mechanically-induced pain (Omote et al. 1996), pain elicited by chemical irritants, and inflammatory pain (Vanegas and Schaible 2000). Mice constitutively lacking the $\mathrm{Ca}_{\mathrm{V}} 2.2$ channels were hyposensitive to inflammatory and neuropathic pain (Hatakeyama et al. 2001; Kim et al. 2001; Saegusa et al. 2001). Generally, $\mathrm{Ca}_{\mathrm{V}} 2.2$ null mice have a mild phenotype that includes deficits for sympathetic control of heart rate and blood pressure (Mori et al. 2002), hyperactivity (Beuckmann et al. 2003), and reduced voluntary ethanol intake and reduced hypnotic response to alcohol (Newton et al. 2004). Because of their exclusive role in nociception and relatively minor contribution to other physiological processes $\mathrm{Ca}_{V} 2.2$ channels are attractive therapeutic target for analgesics.

\section{Regulation of $\mathrm{Ca}_{\mathrm{V}} 2.2$ channels by G-proteins}

Regulation by G-proteins is perhaps the most investigated pathway modulating activity of the $\mathrm{Ca}_{\mathrm{V}} 2.2$ channels. Gproteins are heterotrimers consisting of three subunits $-\alpha$, $\beta$, and $\gamma$. These intracellular complexes are bind to plasma membrane G-protein-coupled receptors (GPCR) (Duc et al. 2015). Activation of GPCR by agonist results in the dissociation of the G-protein heterotrimer into G $\alpha$ and $G \beta \gamma$ subunits. The separated subunits interact with various effectors molecules including an $\alpha_{1}$ subunit of voltage gated calcium channels (Dolphin 1995). Most prominent current modulation by a $\mathrm{G} \beta \gamma$ dimer was described for the $\mathrm{Ca}_{\mathrm{V}} 2.2$ channel (Zhang et al. 1996; Currie and Fox 1997). G $\beta \gamma$ dimer binds directly to the $\alpha_{1}$ subunit of the $\mathrm{Ca}_{V} 2.2$ channels and initiates a transition of the channel from "willing" into "reluctant" gating state (Bean 1989). Reluctant gating state is characterized by a slow activation kinetics, shift of voltage dependence of channel activation towards more positive membrane voltages, and lower whole cell current amplitude (Bean 1989; Hille 1994; Carabelli et al. 1996; Colecraft et al. 2000). Current inhibition caused by G $\beta \gamma$ binding can be relieved by a brief depolarization to positive membrane voltages - so-called prepulse facilitation (Elmslie et al. 1990; Zhang et al. 1996; Currie and Fox 1997; Herlitze et al. 2001). Such mechanism of regulation of calcium entry via $\mathrm{Ca}_{\mathrm{V}} 2.2$ channels enables modulation of neurotransmitter release and consequently modulation of the synaptic transmission of nociceptive signal by activation of synaptic GPRCs.

Reluctant gating state is characterized by a direct binding of the $\mathrm{G} \beta \gamma$ dimer to the $\mathrm{Ca}_{\mathrm{V}} 2.2 \alpha_{1}$ subunit. Multiple interaction sites were identified in the $\mathrm{Ca}_{V} 2.2 \alpha_{1}$ sequence (Figure 2): the aminoterminal part (Page et al. 1998; Stephens et al. 1998; Agler et al. 2005; Page et al. 2010), the intracellular loop connecting domains I and II (De Waard et al. 1997; Herlitze et al. 1997; Page et al. 1997; Simen and Miller 1998; Van Petegem et al. 2004; Tedford et al. 2010), and the carboxyterminal part (Zhang et al. 1996; Qin et al. 1997).

In addition to a direct protein-protein interaction, activation of membrane-located GPRCs in cells expressing $\mathrm{Ca}_{\mathrm{V}} 2.2$ channels stimulates additional modulatory pathways involv-

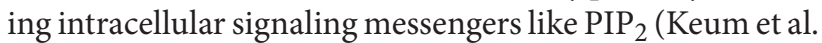
2014) and/or arachidonic acid (Mitra-Ganguli et al. 2009). $\mathrm{PIP}_{2}$-dependent pathway inhibits $\mathrm{N}$-type calcium current by a voltage-independent, $\mathrm{Ca}_{\mathrm{V}} \beta$ subunit isoform-dependent mechanism (Vivas et al. 2013; Keum et al. 2014).

\section{Regulation of $\mathrm{Ca}_{\mathrm{V}} 2.2$ channel by protein kinases}

$\mathrm{Ca}_{V} 2.2$ channels are phosphorylated by protein kinase $\mathrm{C}$ (PKC) isozymes PKCß (Constantin et al. 2017), PKCßII and

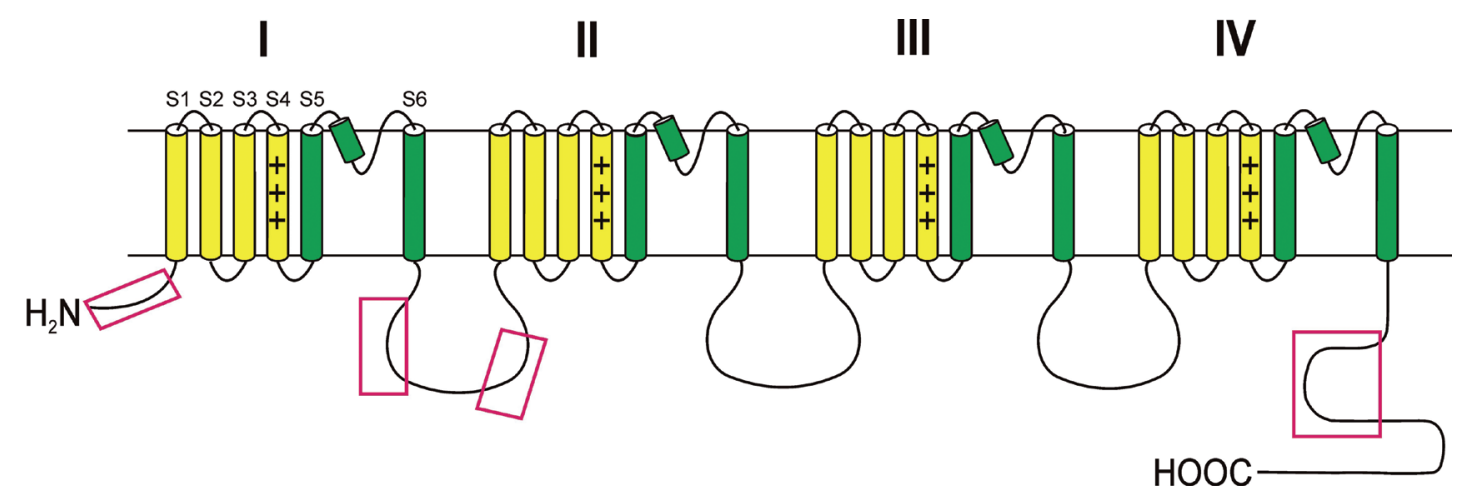

Figure 2. G-protein interaction sites. An outline of primary structure of the $\alpha_{1}$ subunit of N-type calcium channel. Barrels (S1-S6) represent transmembrane segments in domains I-IV. Open boxes indicate regions in the $\alpha_{1}$ subunit sequence interacting with the Gprotein $G \beta \gamma$ subunit. 
PKCع (Rajagopal et al. 2009), and PKC $\delta$ (Rajagopal et al. 2011). This phosphorylation results in a potentiation of N-type calcium current which can be counteracted by a presence of an auxiliary ß subunit (Garcia-Ferreiro et al. 2001; Rajagopal et al. 2014). $\mathrm{Ca}_{V} 2.2$ channel is also constitutively phosphorylated by the calcium/calmodulin-dependent protein kinase II in resting sensory neurons and removal of this phosphorylation result in a loss of channel activity (Kostic et al. 2014).

\section{Protein complexes formed by $\mathrm{Ca}_{\mathrm{V}} 2.2$ channels}

Cav2.2 channels could be functionally regulated by a number of protein-protein interactions. Proteomic analysis focused on identification of such interacting protein networks is fast growing omic research field. Most investigated interaction partners of $\mathrm{Ca}_{\mathrm{V}} 2.2$ channel protein are G-proteins. Other interacting proteins were identified, as well. Activity of $\mathrm{Ca}_{\mathrm{V}} 2.2$ is regulated by the binding of collapsin response mediator protein 2 (CRMP-2) to the channel domain I-II intracellular loop and the distal C terminus and enhances calcium current amplitude without altering its biophysical properties (Brittain et al. 2009; Chi et al. 2009). This interaction requires phosphorylation of CRMP-2 by cyclin-dependent kinase 5 (Brittain et al. 2012; Kim and Ryan 2013). SNARE (soluble NSF attachment receptor) proteins form signaling complex with $\mathrm{Ca}_{\mathrm{V}} 2.2$ channels in presynaptic membrane and mediate exocytosis (Catterall and Few 2008). MAP6 proteins, originally identified as microtubule stabilizing agents, bind to the $\mathrm{Ca}_{V} 2.2$ channel carboxyterminus and this interaction is necessary for proper membrane targeting of the channel protein (Brocard et al. 2017). Coimmunoprecipitation experiments demonstrated that D1 (Kisilevsky et al. 2008) and D2 (Kisilevsky and Zamponi 2008) dopamine receptors form a signaling complex with the $\mathrm{Ca}_{\mathrm{V}} 2.2$ channels. In addition to G-protein-dependent channel modulation, both receptors affect membrane expression level of $\mathrm{Ca}_{\mathrm{V}} 2.2$ channel protein.

More recently, high-throughput assays were used to identify potential $\mathrm{Ca}_{\mathrm{V}} 2.2$-interacting proteins. Screen of presynaptic $\mathrm{Ca}_{\mathrm{V}} 2.2$ complex members by an antibodymediated capture of the channel from purified rat brain synaptosome lysate followed by mass spectroscopy identified 144 potentially interacting proteins (Khanna et al. 2007c). Within the presynaptic transmitter release site (TRS) the $\mathrm{Ca}_{\mathrm{V}} 2.2$ channel associated with Munc18, spectrin, N-ethylmaleimide - sensitive factor (NSF), vesicle associated membrane protein, and $\alpha$-catenin (Khanna et al. 2007a). Analysis of TRS-associated endocytosis protein complex revealed specific binding between $\mathrm{Ca}_{V} 2.2$ channel and H-clathrin, L-clathrin, dynamin, and the adaptor proteins AP180 and intersectin (Khanna et al. 2007b).
Yeast-two hybrid screen identified a direct interaction of the central PDZ domain of RIM protein with carboxyterminus of the $\mathrm{Ca}_{\mathrm{V}} 2.2$ channel (Kaeser et al. 2011). This binding is essential for channel tethering into presynaptic terminal. Another group used the yeast split-ubiquitin system to define the interactome of the $\mathrm{Ca}_{\mathrm{V}} 2.2 \mathrm{Ca}^{2+}$ channel $\alpha_{1}$ subunit and identified tetraspanin-13 (TSPAN-13) (Mallmann et al. 2013), reticulon 1 (RTN1), member 1 of solute carrier family 38 (SLC38), prostaglandin D2 synthase (PTGDS), and transmembrane protein 223 (TMEM223) (Mallmann et al. 2019) as interaction partners of the channel. Detailed electrophysiological studies revealed that TSPAN-13, TMEM223, and, to a lesser extent, PTGDS and SLC38, negatively modulated $\mathrm{Ca}^{2+}$ entry required for transmitter release and/or for dendritic plasticity under physiological conditions. RTN1 modulated $\mathrm{Ca}_{\mathrm{V}} 2.2$ channels only to a minor extent.

\section{Cav2.2 channel-related channelopathies}

Knockout of individual genes in animal models was established as useful tool for gaining insight into the role of specific proteins in (patho)physiology. Mice with constitutive deletion of the $\mathrm{Ca}_{\mathrm{V}} 2.2$ channel are viable and display relatively mild phenotype including hyperactivity (Beuckmann et al. 2003), reduced anxiety (Saegusa et al. 2001), a reduction of voluntary alcohol intake (Newton et al. 2004), and problems with blood pressure control (Mori et al. 2002). Reduced sensitivity to pain in $\mathrm{Ca}_{\mathrm{V}} 2.2^{-/-}$mice confirmed this channel as a prominent target in pain management (Hatakeyama et al. 2001; Kim et al. 2001; Saegusa et al. 2001).

Consistent with the mild phenotype of the $\mathrm{Ca}_{V} 2.2^{-/-}$ mice, reports on mutations linked to a disease phenotype are scarce. Congenital missense mutation resulting in $\mathrm{R} 1389 \mathrm{H}$ amino acid exchange associated with myoclonusdystonia (M-D) syndrome was identified in one family (Groen et al. 2015). When mutated channels were expressed, they conducted lower single-channel current but enhanced whole-cell current. Apparent gain-of-function phenotype can be explained by more frequent openings of mutated channel (Groen et al. 2015) and/or by decreased G-protein-dependent channel inhibition due to longer channel open time (Weiss 2015). Enhanced channel conductance is consistent with symptoms of the disease which include quick, involuntary muscle jerking or twitching (myoclonus). However, other group (Mencacci et al. 2015) contested this work. In their screening of a large cohort of 520 individuals with both familial an sporadic M-D syndrome they detected $\mathrm{R} 1389 \mathrm{H}$ mutation in a single sporadic case with M-D, but in none of the 146 probands with familial M-D. No other mutations related to human heritable diseases were identified until now. 


\section{Blockers of N-type calcium channels in treatment of pain}

Considering their specific involvement in nociception and lack of exclusive role in other physiological processes inhibition of $\mathrm{Ca}_{\mathrm{V}} 2.2$ channels is a promising strategy for treatment of severe chronic pain. Four possible scenarios are available: i) direct inhibition of the channel; ii) inhibition of N-type calcium current by activation of GPCR; iii) inhibition of membrane targeting of the channel protein; iv) disruption of signaling protein complex (Figure 1).

Most known direct $\mathrm{Ca}_{\mathrm{V}} 2.2$ channel blockers are toxins isolated from fish-hunting mollusks. Omega-conotoxin GVIA was identified as a very first specific blocker of the $\mathrm{N}$-type calcium current (Olivera et al. 1984; Reynolds et al. 1986). Currently, number of other conotoxins acting as selective $\mathrm{Ca}_{\mathrm{V}} 2.2$ channel blockers is known (Zamponi et al. 2015). Three novel $\omega$-conotoxins from Conus catus were effective in treatment of inflammatory pain in mice (Sadeghi et al. 2013). In 2005, first FDA (Food and Drug Administration) approval was granted for clinical use of 2005 to $\omega$-conotoxin MVIIA (Prialt, Ziconotide) (Schroeder et al. 2006). However, conotoxin do not cross the blood-brain barrier and must be applied intrathecally. Ziconotide still remains the only clinically used $\mathrm{Ca}_{\mathrm{V}} 2.2$ channel blocker. Recently, series of pyrazolyltetrahydropyran $\mathrm{Ca}_{V} 2.2$ channel blockers was synthesized and tested for potential use in clinics. Two of these compounds did block N-type calcium current in patch clamp assay, were orally bioavailable in rats, and were efficacious in suppressing inflammatory and/or neuropathic pain (Wall et al. 2018). In addition to inhibition of L-type calcium current, some dihydropyridines also block N-type calcium current with high affinity. L/N-type channel blocker cilnidipine lowered post-dialysis systolic blood pressure in a small group of tested patients undergoing hemodialysis (Ito et al. 2019). Intradialytic hypertension is a common complication in such patients. It may be associated with sympathetic overactivity, therefore concurrent inhibition of L-type and N-type calcium current may represent a potential treatment.

Activation of GPRCs results in inhibition of the N-type calcium current by a dissociated G $\beta \gamma$ dimer. Most common clinically used analgesics acting via GPRC is $\mu$-opioid receptor agonist morphine, however, its use is associated with severe side effects including addiction. Agonists of other opioid receptors, i.e., $\kappa, \delta$, and nociceptin, also inhibit $\mathrm{N}$-type calcium current. GPRCs are also coupled to other effectors including G-protein-coupled potassium channels, therefore mechanism of therapeutic action of their ligands is complex and exceeds modulation of $\mathrm{Ca}_{\mathrm{V}} 2.2$ channels (Zamponi et al. 2015).

Trafficking of $\mathrm{Ca}_{\mathrm{V}} 2.2$ channel protein into plasma membrane depends on its interaction with CRMP-2 (Chi et al. 2009). This interaction can be disrupted by small interfering peptides. It was shown that suppression of CRMP-2 binding to the $\mathrm{Ca}_{V} 2.2$ channel complex reduces inflammatory and neuropathic pain (Brittain et al. 2011; Ripsch et al. 2012; Wilson et al. 2012). More detailed knowledge of complex protein-protein interactions in which $\mathrm{Ca}_{\mathrm{V}} 2.2$ channels are involved may open new possibilities for specific suppression of their activation by agents penetrable through the blood-brain barrier allowing better therapeutic approach to intractable pain.

\section{Conclusion}

Altogether, $\mathrm{Ca}_{\mathrm{V}} 2.2$ channels play an unique role in perception of pain. Having minor role in other physiological processes, they represent an attractive target for treatment of severe inflammatory and/or neuropathic pain. As use of blockers acting directly on channel protein is obstructed by their inability to cross blood-brain barrier, knowledge of complex signaling networks regulating $\mathrm{Ca}_{\mathrm{V}} 2.2$ channels may be a promising way for new drug design.

Acknowledgements. Supported by the VEGA grant 2/0107/16.

\section{References}

Agler HL, Evans J, Tay LH, Anderson MJ, Colecraft HM, Yue DT (2005): G protein-gated inhibitory module of N-type (Cav2.2) Ca2+ channels. Neuron 46, 891-904 https://doi.org/10.1016/j.neuron.2005.05.011

Ahlijanian MK, Striessnig J, Catterall WA (1991): Phosphorylation of an a 1-like subunit of an $\omega$-conotoxin-sensitive brain calcium channel by cAMP-dependent protein kinase and protein kinase. J. Biol. Chem. 266, 20192-20197

Bean BP (1989): Neurotransmitter inhibition of neuronal calcium currents by changes in channel voltage dependence. Nature 340, 153-156 https://doi.org/10.1038/340153a0

Beuckmann CT, Sinton CM, Miyamoto N, Ino M, Yanagisawa M (2003): N-type calcium channel a1B subunit (Cav2.2) knockout mice display hyperactivity and vigilance state differences. J. Neurosci. 23, 6793-6797 https://doi.org/10.1523/JNEUROSCI.23-17-06793.2003

Bourinet E, Altier C, Hildebrand ME, Trang T, Salter MW, Zamponi GW (2014): Calcium-permeable ion channels in pain signaling. Physiol. Rev. 94, 81-140 https://doi.org/10.1152/physrev.00023.2013

Brittain JM, Piekarz AD, Wang Y, Kondo T, Cummins TR, Khanna $\mathrm{R}$ (2009): An atypical role for collapsin response mediator protein 2 (CRMP-2) in neurotransmitter release via interaction with presynaptic voltage-gated calcium channels. J. Biol. Chem. 284, 31375-31390 https://doi.org/10.1074/jbc.M109.009951

Brittain JM, Duarte DB, Wilson SM, Zhu W, Ballard C, Johnson PL, Liu N, Xiong W, Ripsch MS, Wang Y, et al. (2011): Sup- 
pression of inflammatory and neuropathic pain by uncoupling CRMP-2 from the presynaptic $\mathrm{Ca} 2+$ channel complex. Nat. Med. 17, 822-829 https://doi.org/10.1038/nm.2345

Brittain JM, Wang Y, Eruvwetere O, Khanna R (2012): Cdk5mediated phosphorylation of CRMP-2 enhances its interaction with CaV2.2. FEBS Lett. 586, 3813-3818 https://doi.org/10.1016/j.febslet.2012.09.022

Brocard J, Dufour F, Gory-Faure S, Arnoult C, Bosc C, Denarier E, Peris L, Saoudi Y, De Waard M, Andrieux A (2017): MAP6 interacts with Tctex 1 and Cav 2.2/N-type calcium channels to regulate calcium signalling in neurons. Eur. J. Neurosci. 46, 2754-2767

https://doi.org/10.1111/ejn.13766

Brust PF, Simerson S, Mccue AF, Deal CR, Schoonmaker S, Williams ME, Velicelebi G, Johnson EC, Harpold MM, Ellis SB (1993): Human neuronal voltage-dependent calcium channels - studies on subunit structure and role in channel assembly. Neuropharmacology 32, 1089-1102 https://doi.org/10.1016/0028-3908(93)90004-M

Buraei Z, Yang JA (2010): The $\beta$ subunit of voltage-gated Ca2+ channels. Physiol. Rev. 90, 1461-1506 https://doi.org/10.1152/physrev.00057.2009

Canti C, Bogdanov Y, Dolphin AC (2000): Interaction between $\mathrm{G}$ proteins and accessory subunits in the regulation of $\mathrm{a} 1 \mathrm{~B}$ calcium channels in Xenopus oocytes. J. Physiol. 527, 419-432 https://doi.org/10.1111/j.1469-7793.2000.t01-1-00419.x

Canti C, Dolphin AC (2003): CaV $\beta$ subunit-mediated up-regulation of CaV2.2 currents triggered by D2 dopamine receptor activation. Neuropharmacology 45, 814-827 https://doi.org/10.1016/S0028-3908(03)00277-6

Carabelli V, Lovallo M, Magnelli V, Zucker H, Carbone E (1996): Voltage-dependent modulation of single N-Type Ca2+ channel kinetics by receptor agonists in IMR32 cells. Biophys. J. 70, 2144-2154 https://doi.org/10.1016/S0006-3495(96)79780-1

Catterall WA, Few AP (2008): Calcium channel regulation and presynaptic plasticity. Neuron $\mathbf{5 9}, \mathbf{8 8 2}-901$ https://doi.org/10.1016/j.neuron.2008.09.005

Chi XX, Schmutzler BS, Brittain JM, Wang Y, Hingtgen CM, Nicol GD, Khanna R (2009): Regulation of N-type voltage-gated calcium channels (Cav2.2) and transmitter release by collapsin response mediator protein-2 (CRMP-2) in sensory neurons. J. Cell Sci. 122, 4351-4362 https://doi.org/10.1242/jcs.053280

Colecraft HM, Patil PG, Yue DT (2000): Differential occurrence of reluctant openings in G-protein-inhibited N- and P/Q-type calcium channels. J. Gen. Physiol. 115, 175-192 https://doi.org/10.1085/jgp.115.2.175

Constantin CE, Muller CS, Leitner MG, Bildl W, Schulte U, Oliver D, Fakler B (2017): Identification of Cav2-PKC $\beta$ a and Cav2-NOS1 complexes as entities for ultrafast electrochemical coupling. Proc. Natl. Acad. Sci. USA 114, 5707-5712 https://doi.org/10.1073/pnas.1616394114

Currie KP, Fox AP (1997): Comparison of N- and P/Q-type voltage-gated calcium channel current inhibition. J. Neurosci. $17,4570-4579$ https://doi.org/10.1523/JNEUROSCI.17-12-04570.1997
De Waard M, Liu H, Walker D, Scott VE, Gurnett CA, Campbell KP (1997): Direct binding of G-protein $\beta \gamma$ complex to voltagedependent calcium channels. Nature 385, 446-450 https://doi.org/10.1038/385446a0

Dolphin AC (1995): The G.LBrown Prize LectureVoltage-dependent calcium channels and their modulation by neurotransmitters and G proteins. Exp. Physiol. 80, 1-36 https://doi.org/10.1113/expphysiol.1995.sp003825

Dolphin AC (2012): Calcium channel auxiliary $\alpha 2 \delta$ and $\beta$ subunits: trafficking and one step beyond. Nat. Rev. Neurosci. 13, 542-555 https://doi.org/10.1038/nrn3311

Dubel SJ, Starr TV, Hell J, Ahlijanian MK, Enyeart JJ, Catterall WA, Snutch TP (1992): Molecular cloning of the $\alpha-1$ subunit of an $\omega$-conotoxin-sensitive calcium channel. Proc. Natl. Acad. Sci. USA 89, 5058-5062

https://doi.org/10.1073/pnas.89.11.5058

Duc NM, Kim HR, Chung KY (2015): Structural mechanism of $\mathrm{G}$ protein activation by $\mathrm{G}$ protein-coupled receptor. Eur. J. Pharmacol. 763, 214-222 https://doi.org/10.1016/j.ejphar.2015.05.016

Elmslie KS, Zhou W, Jones SW (1990): LHRH and GTP- $\gamma$-S modify calcium current activation in bullfrog sympathetic neurons. Neuron 5, 75-80 https://doi.org/10.1016/0896-6273(90)90035-E

Ertel EA, Campbell KP, Harpold MM, Hofmann F, Mori Y, PerezReyes E, Schwartz A, Snutch TP, Tanabe T, Birnbaumer L, et al. (2000): Nomenclature of voltage-gated calcium channels. Neuron 25, 533-535 https://doi.org/10.1016/S0896-6273(00)81057-0

Ferron L, Nieto-Rostro M, Cassidy JS, Dolphin AC (2014): Fragile $\mathrm{X}$ mental retardation protein controls synaptic vesicle exocytosis by modulating $\mathrm{N}$-type calcium channel density. Nat. Commun. 5, 3628 https://doi.org/10.1038/ncomms4628

Gao B, Sekido Y, Maximov A, Saad M, Forgacs E, Latif F, Wei MH, Lerman M, Lee JH, Perez-Reyes E, Bezprozvanny I, Minna JD (2000): Functional properties of a new voltage-dependent calcium channel $\alpha 2 \delta$ auxiliary subunit gene (CACNA2D2). J. Biol. Chem. 275, 12237-12242 https://doi.org/10.1074/jbc.275.16.12237

Garcia-Ferreiro RE, Hernandez-Ochoa EO, Garcia DE (2001): Modulation of N-type Ca2+ channel current kinetics by PMA in rat sympathetic neurons. Pflugers. Arch. 442, 848-858 https://doi.org/10.1007/s004240100618

Groen JL, Andrade A, Ritz K, Jalalzadeh H, Haagmans M, Bradley TE, Jongejan A, Verbeek DS, Nurnberg P, Denome S, et al. (2015): CACNA1B mutation is linked to unique myoclonusdystonia syndrome. Hum. Mol. Genet. 24, 987-993 https://doi.org/10.1093/hmg/ddu513

Gross RA, Macdonald RL (1987): Dynorphin A selectively reduces a large transient (N-type) calcium current of mouse dorsal root ganglion neurons in cell culture. Proc. Natl. Acad. Sci. USA 84, 5469-5473 https://doi.org/10.1073/pnas.84.15.5469

Hatakeyama S, Wakamori M, Ino M, Miyamoto N, Takahashi E, Yoshinaga T, Sawada K, Imoto K, Tanaka I, Yoshizawa T, et al. (2001): Differential nociceptive responses in mice lacking 
the a1B subunit of N-type Ca2+ channels. Neuroreport 12, 2423-2427

https://doi.org/10.1097/00001756-200108080-00027

Herlitze S, Hockerman GH, Scheuer T, Catterall WA (1997): Molecular determinants of inactivation and $\mathrm{G}$ protein modulation in the intracellular loop connecting domains I and II of the calcium channel a1A subunit. Proc. Natl. Acad. Sci. USA 94, $1512-1516$ https://doi.org/10.1073/pnas.94.4.1512

Herlitze S, Zhong H, Scheuer T, Catterall WA (2001): Allosteric modulation of $\mathrm{Ca} 2+$ channels by $\mathrm{G}$ proteins, voltage-dependent facilitation, protein kinase $C$, and $\operatorname{Cav} \beta$ subunits. Proc. Natl. Acad. Sci. USA 98, 4699-4704 https://doi.org/10.1073/pnas.051628998

Hille B (1994): Modulation of ion-channel function by G-proteincoupled receptors. Trends Neurosci. 17, 531-536 https://doi.org/10.1016/0166-2236(94)90157-0

Ito T, Fujimoto N, Ishikawa E, Dohi K, Fujimoto M, Murata T, Kiyohara M, Takeuchi H, Koyabu S, Nishimura H, Takeuchi T, Ito M (2019): The effect of an L/N-type calcium channel blocker on intradialytic blood pressure in intradialytic hypertensive patients. Clin. Exp. Hypertens. 41, 92-99 https://doi.org/10.1080/10641963.2018.1445753

Kaeser PS, Deng L, Wang Y, Dulubova I, Liu X, Rizo J, Sudhof TC (2011): RIM proteins tether Ca2+ channels to presynaptic active zones via a direct PDZ-domain interaction. Cell 144, 282-295 https://doi.org/10.1016/j.cell.2010.12.029

Kasai H, Aosaki T, Fukuda J (1987): Presynaptic Ca-antagonist $\omega$-conotoxin irreversibly blocks $\mathrm{N}$-type Ca-channels in chick sensory neurons. Neurosci. Res. 4, 228-235 https://doi.org/10.1016/0168-0102(87)90014-9

Keum D, Baek C, Kim DI, Kweon HJ, Suh BC (2014): Voltagedependent regulation of CaV2.2 channels by Gq-coupled receptor is facilitated by membrane-localized beta subunit. J. Gen. Physiol. 144, 297-309 https://doi.org/10.1085/jgp.201411245

Khanna R, Li Q, Bewersdorf J, Stanley EF (2007a): The presynaptic CaV2.2 channel-transmitter release site core complex. Eur. J. Neurosci. 26, 547-559 https://doi.org/10.1111/j.1460-9568.2007.05680.x

Khanna R, Li Q, Schlichter LC, Stanley EF (2007b): The transmitter release-site CaV2.2 channel cluster is linked to an endocytosis coat protein complex. Eur. J. Neurosci. 26, 560-574 https://doi.org/10.1111/j.1460-9568.2007.05681.x

Khanna R, Zougman A, Stanley EF (2007c): A proteomic screen for presynaptic terminal N-type calcium channel (CaV2.2) binding partners. J. Biochem. Mol. Biol. 40, 302-314

Kim C, Jun K, Lee T, Kim SS, McEnery MW, Chin H, Kim HL, Park JM, Kim DK, Jung SJ, et al. (2001): Altered nociceptive response in mice deficient in the a1B subunit of the voltage-dependent calcium channel. Mol. Cell Neurosci. 18, 235-245 https://doi.org/10.1006/mcne.2001.1013

Kim SH, Ryan TA (2013): Balance of calcineurin Aa and CDK5 activities sets release probability at nerve terminals. J. Neurosci. 33, $8937-8950$ https://doi.org/10.1523/JNEUROSCI.4288-12.2013

Kisilevsky AE, Mulligan SJ, Altier C, Iftinca MC, Varela D, Tai C, Chen L, Hameed S, Hamid J, Macvicar BA, Zamponi GW
(2008): D1 receptors physically interact with N-type calcium channels to regulate channel distribution and dendritic calcium entry. Neuron 58, 557-570

https://doi.org/10.1016/j.neuron.2008.03.002

Kisilevsky AE, Zamponi GW (2008): D2 dopamine receptors interact directly with $\mathrm{N}$-type calcium channels and regulate channel surface expression levels. Channels (Austin) 2, 269-277 https://doi.org/10.4161/chan.2.4.6402

Kostic S, Pan B, Guo Y, Yu H, Sapunar D, Kwok WM, Hudmon A, Wu HE, Hogan QH (2014): Regulation of voltage-gated Ca2+ currents by $\mathrm{Ca} 2+/$ calmodulin-dependent protein kinase II in resting sensory neurons. Mol. Cell Neurosci. 62, 10-18 https://doi.org/10.1016/j.mcn.2014.07.004

Mallmann R, Ondacova K, Moravcikova L, Jurkovicova-Tarabova B, Pavlovicova M, Lichvarova L, Kominkova V, Klugbauer N, Lacinova L (2019): Four novel interaction partners demonstrate diverse modulatory effects on voltage-gated CaV2.2 Ca2+ channels. Pflugers Arch. (in press)

https://doi.org/10.1007/s00424-018-02248-x

Mallmann RT, Wilmes T, Lichvarova L, Buhrer A, Lohmuller B, Castonguay J, Lacinova L, Klugbauer N (2013): Tetraspanin-13 modulates voltage-gated CaV2.2 Ca2+ channels. Sci. Rep. 3, 1777 https://doi.org/10.1038/srep01777

Malmberg AB, Yaksh TL (1994a): Antinociception produced by spinal delivery of the $\mathrm{S}$ and $\mathrm{R}$ enantiomers of flurbiprofen in the formalin test. Eur. J. Pharmacol. 256, 205-209 https://doi.org/10.1016/0014-2999(94)90247-X

Malmberg AB, Yaksh TL (1994b): Voltage-sensitive calcium channels in spinal nociceptive processing: blockade of $\mathrm{N}$ - and P-type channels inhibits formalin-induced nociception. J. Neurosci. 14, 4882-4890 https://doi.org/10.1523/JNEUROSCI.14-08-04882.1994

McEnery MW, Snowman AM, Sharp AH, Adams ME, Snyder SH (1991): Purified $\omega$-conotoxin GVIA receptor of rat brain resembles a dihydropyridine-sensitive L-type calcium channel. Proc. Natl. Acad. Sci. USA 88, 11095-11099 https://doi.org/10.1073/pnas.88.24.11095

Mencacci NE, R'Bibo L, Bandres-Ciga S, Carecchio M, Zorzi G, Nardocci N, Garavaglia B, Batla A, Bhatia KP, Pittman AM, et al. (2015): The CACNA1B R1389H variant is not associated with myoclonus-dystonia in a large European multicentric cohort. Hum. Mol. Genet. 24, 5326-5329 https://doi.org/10.1093/hmg/ddv255

Mitra-Ganguli T, Vitko I, Perez-Reyes E, Rittenhouse AR (2009): Orientation of palmitoylated $\mathrm{CaV} \beta 2 \mathrm{a}$ relative to $\mathrm{CaV} 2.2$ is critical for slow pathway modulation of N-type $\mathrm{Ca} 2+$ current by tachykinin receptor activation. J. Gen. Physiol. 134, 385-396 https://doi.org/10.1085/jgp.200910204

Mori Y, Nishida M, Shimizu S, Ishii M, Yoshinaga T, Ino M, Sawada $\mathrm{K}$, Niidome $\mathrm{T}$ (2002): Ca2+ channel a1B subunit ( $\mathrm{CaV} 2.2)$ knockout mouse reveals a predominant role of $\mathrm{N}$-type channels in the sympathetic regulation of the circulatory system. Trends Cardiovasc. Med. 12, 270-275 https://doi.org/10.1016/S1050-1738(02)00173-1

Muller CS, Haupt A, Bildl W, Schindler J, Knaus HG, Meissner M, Rammner B, Striessnig J, Flockerzi V, Fakler B, Schulte U 
(2010): Quantitative proteomics of the Cav2 channel nanoenvironments in the mammalian brain. Proc. Natl. Acad. Sci. USA 107, 14950-14957

https://doi.org/10.1073/pnas.1005940107

Newton PM, Orr CJ, Wallace MJ, Kim C, Shin HS, Messing RO (2004): Deletion of N-type calcium channels alters ethanol reward and reduces ethanol consumption in mice. J. Neurosci. 24, 9862-9869 https://doi.org/10.1523/JNEUROSCI.3446-04.2004

Nieto-Rostro M, Ramgoolam K, Pratt WS, Kulik A, Dolphin AC (2018): Ablation of $a 2 \delta-1$ inhibits cell-surface trafficking of endogenous $\mathrm{N}$-type calcium channels in the pain pathway in vivo. Proc. Natl. Acad. Sci. USA 115, E12043-12052 https://doi.org/10.1073/pnas.1811212115

Nowycky MC, Fox AP, Tsien RW (1985): Three types of neuronal calcium channel with different calcium agonist sensitivity. Nature 316, 440-443 https://doi.org/10.1038/316440a0

Olivera BM, McIntosh JM, Cruz LJ, Luque FA, Gray WR (1984): Purification and sequence of a presynaptic peptide toxin from Conus geographus venom. Biochemistry 23, 5087-5090 https://doi.org/10.1021/bi00317a001

Omote K, Kawamata M, Satoh O, Iwasaki H, Namiki A (1996): Spinal antinociceptive action of an N-Type voltage-dependent calcium channel blocker and the synergistic interaction with morphine. Anesthesiology 84, 636-643 https://doi.org/10.1097/00000542-199603000-00019

Page KM, Stephens GJ, Berrow NS, Dolphin AC (1997): The intracellular loop between domains I and II of the B-type calcium channel confers aspects of G-protein sensitivity to the E-type calcium channel. J. Neurosci. 17, 1330-1338 https://doi.org/10.1523/JNEUROSCI.17-04-01330.1997

Page KM, Canti C, Stephens GJ, Berrow NS, Dolphin AC (1998): Identification of the amino terminus of neuronal $\mathrm{Ca} 2+$ channel $\alpha 1$ subunits $\alpha 1 \mathrm{~B}$ and $\alpha 1 \mathrm{E}$ as an essential determinant of G-protein modulation. J. Neurosci. 18, 4815-4824 https://doi.org/10.1523/JNEUROSCI.18-13-04815.1998

Page KM, Heblich F, Margas W, Pratt WS, Nieto-Rostro M, Chaggar K, Sandhu K, Davies A, Dolphin AC (2010): N terminus is key to the dominant negative suppression of $\mathrm{CaV} 2$ calcium channels: implications for episodic ataxia type 2. J. Biol. Chem. 285, 835-844 https://doi.org/10.1074/jbc.M109.065045

Pragnell M, Sakamoto J, Jay SD, Campbell KP (1991): Cloning and tissue-specific expression of the brain calcium channel $\beta$-subunit. FEBS Lett. 291, 253-258 https://doi.org/10.1016/0014-5793(91)81296-K

Qin N, Platano D, Olcese R, Stefani E, Birnbaumer L (1997): Direct interaction of $G \beta \gamma$ with a C-terminal $G \beta \gamma$-binding domain of the $\mathrm{Ca} 2+$ channel a1 subunit is responsible for channel inhibition by $\mathrm{G}$ protein-coupled receptors. Proc. Natl. Acad. Sci. USA 94, 8866-8871 https://doi.org/10.1073/pnas.94.16.8866

Rajagopal S, Fang H, Oronce CI, Jhaveri S, Taneja S, Dehlin EM, Snyder SL, Sando JJ, Kamatchi GL. (2009): Site-specific regulation of $\mathrm{CA}(\mathrm{V}) 2.2$ channels by protein kinase $\mathrm{C}$ isozymes $\beta \mathrm{II}$ and $\varepsilon$. Neuroscience 159, 618-628 https://doi.org/10.1016/j.neuroscience.2008.12.047
Rajagopal S, Fang H, Lynch C, 3rd, Sando JJ, Kamatchi GL (2011): Effects of isoflurane on the expressed Cav2.2 currents in Xenopus oocytes depend on the activation of protein kinase $\mathrm{C} \delta$ and its phosphorylation sites in the Cav2.2a1 subunits. Neuroscience 182, 232-240 https://doi.org/10.1016/j.neuroscience.2011.02.041

Rajagopal S, Fields BL, Burton BK, On C, Reeder AA, Kamatchi GL (2014): Inhibition of protein kinase C (PKC) response of voltage-gated calcium (Cav)2.2 channels expressed in Xenopus oocytes by $\operatorname{Cav} \beta$ subunits. Neuroscience 280, 1-9 https://doi.org/10.1016/j.neuroscience.2014.08.049

Reynolds IJ, Wagner JA, Snyder SH, Thayer SA, Olivera BM, Miller RJ (1986): Brain voltage-sensitive calcium channel subtypes differentiated by $\omega$-conotoxin fraction GVIA. Proc. Natl. Acad. Sci. USA 83, 8804-8807 https://doi.org/10.1073/pnas.83.22.8804

Ripsch MS, Ballard CJ, Khanna M, Hurley JH, White FA, Khanna $\mathrm{R}$ (2012): A peptide uncoupling CRMP-2 from the presynaptic $\mathrm{Ca} 2+$ channel complex demonstrates efficacy in animal models of migraine and aids therapy-induced neuropathy. Transl. Neurosci. 3, 1-8 https://doi.org/10.2478/s13380-012-0002-4

Sadeghi M, Murali SS, Lewis RJ, Alewood PF, Mohammadi S, Christie MJ (2013): Novel omega-conotoxins from Ccatus reverse signs of mouse inflammatory pain after systemic administration. Mol. Pain 9, 51 https://doi.org/10.1186/1744-8069-9-51

Saegusa H, Kurihara T, Zong S, Kazuno A, Matsuda Y, Nonaka T, Han W, Toriyama H, Tanabe T (2001): Suppression of inflammatory and neuropathic pain symptoms in mice lacking the N-type Ca2+ channel. EMBO J. 20, 2349-2356 https://doi.org/10.1093/emboj/20.10.2349

Scott VE, De Waard M, Liu H, Gurnett CA, Venzke DP, Lennon VA, Campbell KP (1996): Beta subunit heterogeneity in N-type Ca2+ channels. J. Biol. Chem. 271, 3207-3212 https://doi.org/10.1074/jbc.271.6.3207

Sheng ZH, Rettig J, Takahashi M, Catterall WA (1994): Identification of a syntaxin-binding site on N-type calcium channels. Neuron 13, 1303-1313 https://doi.org/10.1016/0896-6273(94)90417-0

Sheng ZH, Rettig J, Cook T, Catterall WA (1996): Calcium-dependent interaction of $\mathrm{N}$-type calcium channels with the synaptic core complex. Nature 379, 451-454 https://doi.org/10.1038/379451a0

Schroeder CI, Doering CJ, Zamponi GW, Lewis RJ (2006): N-type calcium channel blockers: novel therapeutics for the treatment of pain. Med. Chem. 2, 535-543 https://doi.org/10.2174/157340606778250216

Simen AA, Miller RJ (1998): Structural features determining differential receptor regulation of neuronal Ca channels. J. Neurosci. 18, 3689-3698 https://doi.org/10.1523/JNEUROSCI.18-10-03689.1998

Snutch TP, Leonard JP, Gilbert MM, Lester HA, Davidson N (1990): Rat brain expresses a heterogeneous family of calcium channels. Proc. Natl. Acad. Sci. USA 87, 3391-3395 https://doi.org/10.1073/pnas.87.9.3391

Stea A, Dubel SJ, Pragnell M, Leonard JP, Campbell KP, Snutch TP (1993): A beta-subunit normalizes the electrophysiologi- 
cal properties of a cloned $\mathrm{N}$-type $\mathrm{Ca} 2+$ channel $\alpha 1$-subunit. Neuropharmacology 32, 1103-1116 https://doi.org/10.1016/0028-3908(93)90005-N

Stephens GJ, Canti C, Page KM, Dolphin AC (1998): Role of domain I of neuronal $\mathrm{Ca} 2+$ channel a 1 subunits in $\mathrm{G}$ protein modulation. J. Physiol. 509, 163-169 https://doi.org/10.1111/j.1469-7793.1998.163bo.x

Stephens GJ, Page KM, Bogdanov Y, Dolphin AC (2000): The alpha $1 \mathrm{~B} \mathrm{Ca} 2+$ channel amino terminus contributes determinants for $\beta$ subunit-mediated voltage-dependent inactivation properties. J. Physiol. 525, 377-390 https://doi.org/10.1111/j.1469-7793.2000.t01-1-00377.x

Tedford HW, Kisilevsky AE, Vieira LB, Varela D, Chen L, Zamponi GW (2010): Scanning mutagenesis of the I-II loop of the Cav2.2 calcium channel identifies residues Arginine 376 and Valine 416 as molecular determinants of voltage dependent $G$ protein inhibition. Mol. Brain 3, 6 https://doi.org/10.1186/1756-6606-3-6

Van Petegem F, Clark KA, Chatelain FC, Minor DL, Jr (2004): Structure of a complex between a voltage-gated calcium channel $\beta$-subunit and an $\alpha$-subunit domain. Nature 429, 671-675 https://doi.org/10.1038/nature02588

Vanegas H, Schaible H (2000): Effects of antagonists to highthreshold calcium channels upon spinal mechanisms of pain, hyperalgesia and allodynia. Pain 85, 9-18 https://doi.org/10.1016/S0304-3959(99)00241-9

Vivas O, Castro H, Arenas I, Elias-Vinas D, Garcia DE (2013): PIP (2) hydrolysis is responsible for voltage independent inhibition of CaV2.2 channels in sympathetic neurons. Biochem. Biophys. Res. Commun. 432, 275-280 https://doi.org/10.1016/j.bbrc.2013.01.117

Wakamori M, Mikala G, Mori Y (1999): Auxiliary subunits operate as a molecular switch in determining gating behaviour of the unitary N-type Ca2+ channel current in Xenopus oocytes. J. Physiol. 517, 659-672 https://doi.org/10.1111/j.1469-7793.1999.0659s.x

Wall MJ, Subasinghe NL, Winters MP, Lubin ML, Finley MFA, Qin N, Brandt MR, Neeper MP, Schneider CR, Colburn RW, et al. (2018): Discovery and optimization of a novel series of pyrazolyltetrahydropyran N-type calcium channel (Cav 2.2) blockers for the treatment of pain. Bioorg. Med. Chem. Lett. 28, 3780-3783 https://doi.org/10.1016/j.bmcl.2018.10.007

Wanke E, Ferroni A, Malgaroli A, Ambrosini A, Pozzan T, Meldolesi $J$ (1987): Activation of a muscarinic receptor selectively inhibits a rapidly inactivated $\mathrm{Ca} 2+$ current in rat sympathetic neurons. Proc. Natl. Acad. Sci. USA 84, 4313-4317 https://doi.org/10.1073/pnas.84.12.4313

Weber AM, Wong FK, Tufford AR, Schlichter LC, Matveev V, Stanley EF (2010): N-type Ca2+ channels carry the largest current: implications for nanodomains and transmitter release. Nat. Neurosci. 13, 1348-1350 https://doi.org/10.1038/nn.2657

Weiss N (2015): The first disease connection for Cav2.2 channels. Gen. Physiol. Biophys. 34, 217-219

https://doi.org/10.4149/gpb_2015014

Westenbroek RE, Hell JW, Warner C, Dubel SJ, Snutch TP, Catterall WA (1992): Biochemical properties and subcellular distribution of an N-type calcium channel al subunit. Neuron 9, 1099-1115 https://doi.org/10.1016/0896-6273(92)90069-P

Westenbroek RE, Hoskins L, Catterall WA (1998): Localization of $\mathrm{Ca} 2+$ channel subtypes on rat spinal motor neurons, interneurons, and nerve terminals. J. Neurosci. 18, 6319-6330 https://doi.org/10.1523/JNEUROSCI.18-16-06319.1998

Williams ME, Brust PF, Feldman DH, Patthi S, Simerson S, Maroufi A, McCue AF, Velicelebi G, Ellis SB, Harpold MM (1992a): Structure and functional expression of an omega-conotoxinsensitive human N-type calcium channel. Science 257, 389-395 https://doi.org/10.1126/science.1321501

Williams ME, Feldman DH, McCue AF, Brenner R, Velicelebi G, Ellis SB, Harpold MM (1992b): Structure and functional expression of $\alpha 1, \alpha 2$, and $\beta$ subunits of a novel human neuronal calcium channel subtype. Neuron 8, 71-84 https://doi.org/10.1016/0896-6273(92)90109-Q

Wilson SM, Schmutzler BS, Brittain JM, Dustrude ET, Ripsch MS, Pellman JJ, Yeum TS, Hurley JH, Hingtgen CM, White FA, Khanna R (2012): Inhibition of transmitter release and attenuation of anti-retroviral-associated and tibial nerve injury-related painful peripheral neuropathy by novel synthetic $\mathrm{Ca} 2+$ channel peptides. J. Biol. Chem. 287, 35065-35077 https://doi.org/10.1074/jbc.M112.378695

Witcher DR, De Waard M, Sakamoto J, Franzini-Armstrong C, Pragnell M, Kahl SD, Campbell KP (1993): Subunit identification and reconstitution of the N-type $\mathrm{Ca} 2+$ channel complex purified from brain. Science 261, 486-489 https://doi.org/10.1126/science.8392754

Yasuda T, Lewis RJ, Adams DJ (2004): Overexpressed Ca-v $\beta 3$ inhibits $\mathrm{N}$-type (Cav2.2) calcium channel currents through a hyperpolarizing shift of „ultra-slow" and „closed-state“ inactivation. J. Gen. Physiol. 123, 401-416 https://doi.org/10.1085/jgp.200308967

Zamponi GW, Striessnig J, Koschak A, Dolphin AC (2015): The physiology, pathology, and pharmacology of voltage-gated calcium channels and their future therapeutic potential. Pharmacol. Rev. 67, 821-870

https://doi.org/10.1124/pr.114.009654

Zhang JF, Ellinor PT, Aldrich RW, Tsien RW (1996): Multiple structural elements in voltage-dependent $\mathrm{Ca} 2+$ channels support their inhibition by G proteins. Neuron 17, 991-1003 https://doi.org/10.1016/S0896-6273(00)80229-9

Received: January 9, 2019

Final version accepted: January 15, 2019

First published online: March 1, 2019 